\title{
Identification of preadmission predictors of outcome of noninvasive ventilation in acute exacerbation of chronic obstructive pulmonary disease
}

\author{
Mohd. Shameem, Rakesh Bhargava, Zuber Ahmad
}

\begin{abstract}
Background: Noninvasive ventilation (NIV) has been shown to be an effective treatment for ventilatory failure, particularly resulting from acute exacerbations of chronic obstructive pulmonary disease (COPD). However, NIV is associated with significant failure rates. Hence, there is a need for identifying preadmission predictors for outcome of NIV in patients for acute exacerbation of COPD, thereby sparing the discomfort of a trial of NIV on these patients. Aim: The study was carried to identify the preadmission predictors of outcome of NIV in acute exacerbation of COPD with respiratory failure. Material and Methods: The study was carried in the Department of TB \& Chest diseases at the Jawaharlal Nehru Medical College, AMU; 250 patients with acute exacerbation of COPD were enrolled in the study. These patients were grouped on the basis of six different independent variables, viz. age, performance status, $\mathrm{pH}$, late failures, $\mathrm{SaO}_{2}$, and presence or absence of pedal edema. Analysis was done by $z$-test, $\mathrm{P}<0.001$ was considered significant. Observation: Age had no impact on the outcome of patient on NIV $(z=0.3)$. The risk for endotracheal intubation was found to be increased by the presence of pedal edema $(z=6.2 ; \mathrm{P}<0.001), \mathrm{O}_{2}$ saturation of less than $86 \%(z=4.7 ; \mathrm{P}<0.001)$, and acidemia $(\mathrm{pH}<7.3)$ on admission $(z=10.6 ; \mathrm{P}<0.001)$. In addition, poor performance status of limited self-care $(z=3.2 ; \mathrm{P}<0.01)$ and late failures carried poor outcome of NIV $(z=8.3 ; P<0.001)$. Conclusion: Patients' COPD with poor baseline performance status, pedal edema, low oxygen saturation, and academia carry a high likelihood of failure and should be spared a prolonged trial of NIV.
\end{abstract}

Key Words: Chronic obstructive pulmonary disease, Endotracheal intubation, Noninvasive ventilation

\section{Introduction}

The use of noninvasive ventilation (NIV) in the management of chronic obstructive pulmonary disease (COPD) is now supported by a number of randomized controlled trials. ${ }^{[1-5]}$ It has been shown to reduce intubation rates, ${ }^{[3-5]}$ mortality, ${ }^{[2-5]}$ and length of hospital stay. ${ }^{[1-4]}$

\section{From:}

Department of Tuberculosis and Chest Diseases, Jawaharlal Nehru Medical College, Aligarh Muslim University, Aligarh, Uttar Pradesh 202002, India

\section{Correspondence:}

Mohd. Shameem, Departments of TB and Chest Diseases, Jawaharlal Nehru Medical College, Aligarh Muslim University, Aligarh, Uttar Pradesh 202002, India. E-mail: doctor_shameem123@rediffmail.com
It has the advantage that it can be applied intermittently, avoids the need for sedation, and allows the patient to eat, drink, and speak. The incidence of nosocomial pneumonia during NIV is lower than in intubated patients. ${ }^{[6]}$ However, NIV is not successful in all cases of acute on chronic respiratory failures owing to COPD, with reported failure rates of $7-50 \% .{ }^{[4]}$ There has also been concern that NIV may delay intubation, leading to a worse outcome. ${ }^{[7,8]}$ The ability to predict those likely to fail with NIV is important. Patients in whom there is a likelihood of failure would be spared the discomfort of a trail of NIV and intubation would not be delayed. 


\section{Materials and Methods}

The study was carried in the Department of TB \& Chest Diseases, Jawaharlal Nehru Medical College, AMU, between January 2001 and June 2003. Bilevel positive airways pressure (model-horizon) was used for the study. The patients were managed in the high dependency unit in the Department of Tuberculosis and Chest Diseases; 250 patients with acute exacerbation of COPD were enrolled in the study. Informed consent was taken from all these patients. The following data were obtained for all patients before initiation of NIV: age, sex, weight, vital signs (systemic arterial blood pressure, heart rate, and respiratory rate). Arterial blood gas analysis (ABG) was obtained at regular intervals ( $0 \mathrm{~h}, 30 \mathrm{~min}, 1 \mathrm{~h}, 2 \mathrm{~h})$. All patients were given conventional medical therapy in addition to NIV. The inclusion criteria were respiratory distress with respiratory rate more than $24 / \mathrm{min}, \mathrm{pH}$ range 7.2-7.42, $\mathrm{SaO}_{2}$ between $82 \%$ and $98 \%$, performance status ranging from normal activity (NA) to bed care and no self-care $(\mathrm{BC})$, presence of pedal edema, late failures (i.e., deterioration after $48 \mathrm{~h}$ of NIV). Exclusion criteria were cardiac or respiratory arrest, upper gastrointestinal bleed, comatose patients, hypotension inspite of inotropes, arrhythmias, poor gag reflex, and $\mathrm{pH}<7.20$. Criteria for NIV discontinuation and endotracheal intubation were mask intolerance owing to pain, discomfort, or claustrophobia, inability to improve gas exchange after $2 \mathrm{~h}$ of NIV, hemodynamic instability or evidence of cardiac ischemia or ventricular dysarrhythmia, and need for urgent endotracheal intubation to manage secretions or protect the airways. NIV was applied initially for $2 \mathrm{~h}$ to assess the improvement ( $A B G$ was done at $0 \mathrm{~h}, 30 \mathrm{~min}, 1 \mathrm{~h}$, and $2 \mathrm{~h}$ ). However, if the patient falls under the criteria for NIV discontinuation and endotracheal intubation before $2 \mathrm{~h}$, the trail of NIV was discontinued. The starting pressures were as follows: $6 \mathrm{~cm} \mathrm{H}_{2} \mathrm{O}$ Inspiratory Positive Airway Pressure (IPAP) and $4 \mathrm{~cm} \mathrm{H}_{2} \mathrm{O}$ Expiratory Positive Airway Pressure (EPAP) (difference of at least $2 \mathrm{~cm} \mathrm{H}_{2} \mathrm{O}$ was maintained), it was gradually increased according to patient compliance up to maximum IPAP of $18 \mathrm{~cm} \mathrm{H}_{2} \mathrm{O}$ and EPAP of $16 \mathrm{~cm} \mathrm{H}_{2} \mathrm{O}$. Statistical analysis was done by $z$ test, $P<0.01$ was considered statistically significant.

\section{Observation}

Data available at the time of NIV is initiated and after a short period (30 min, $1 \mathrm{~h}$ ) can predict the likelihood of success or failure with reasonable degree of precision.
Out of 250 patients enrolled in the study, most of the patients were of age group $70-75(n=70)$ and $27 \%$ of patient of this age group (19 patients) had to undergo endotracheal intubation; however, the result was statistically not significant (Table 1; Figure 1).

Patients with performance status of limited self-care carry worst prognosis as compared with patients with normal activity $(z=3.2 ; P<0.01)$, as compared with patients of limited strenuous activity $(z=3.0 ; P<0.01)$, as compared with patients of bed care and no self-care $(z=$ 0.2 ; not significant, Table 2; Figure 2). Patients with oxygen saturation in the range $92-98 \%$ at the time of admission carry better prognosis $(z=4.7 ; P<0.001)$ as compared with patients with oxygen saturation $<92 \%$ (Table 3; Figure 3).Patients with $\mathrm{pH}$ range 7.20-7.26 carry poor prognosis and require endotracheal intubation; (Table 4; Figure 4). Patients with pedal edema indicating cor-pulmonale carry poor prognosis $(P<0.001$,

\begin{tabular}{lccc}
\hline \multicolumn{4}{l}{ Table 1: Effect of age on outcome of NIV } \\
\hline Age & $\begin{array}{c}\text { Number of } \\
\text { (years) }\end{array}$ & $\begin{array}{c}\text { Patients requiring } \\
\text { patients }\end{array}$ & $\begin{array}{c}\text { Statistical } \\
\text { endotracheal intubation } \\
\text { analysis }(z)\end{array}$ \\
$50-55$ & 25 & 6 & 0.3 \\
$55-60$ & 30 & 7 & 0.4 \\
$60-65$ & 50 & 10 & 0.8 \\
$70-75$ & 70 & 19 & 0 \\
$75-80$ & 25 & 8 & 0.5 \\
\hline
\end{tabular}

\begin{tabular}{lccc}
\hline Table 2: Effect of performance status on outcome of NIV \\
$\begin{array}{l}\text { Performance } \\
\text { status }\end{array}$ & $\begin{array}{l}\text { Number of } \\
\text { patients }\end{array}$ & $\begin{array}{l}\text { Patients } \\
\text { requiring } \\
\text { endotracheal } \\
\text { intubation }\end{array}$ & $\begin{array}{l}\text { Statistical } \\
\text { analysis }\end{array}$ \\
NA & 20 & 1 & $Z=3.2 ; P<0.01$ \\
$\begin{array}{l}\text { Strenuous activity } \\
\text { (SA)-limited }\end{array}$ & 30 & 4 & $Z=4 ; P<0.01$ \\
$\begin{array}{l}\text { Limited but } \\
\text { self-care (L/SC) }\end{array}$ & 90 & 20 & $Z=3 ; P<0.01$ \\
Limited self-care & 70 & 30 & \\
BC & 40 & 18 & $Z=0.2 ; P<0.2$ \\
\hline
\end{tabular}

Table 3: Effect of oxygen saturation $\left(\mathrm{SaO}_{2}\right)$ on outcome of NIV

\begin{tabular}{lccl}
\hline $\mathrm{SaO}_{2}$ & $\begin{array}{c}\text { Number of } \\
\text { patients }\end{array}$ & $\begin{array}{l}\text { Patients requiring } \\
\text { endotracheal intubation }\end{array}$ & $\begin{array}{l}\text { Statistical } \\
\text { analysis }\end{array}$ \\
$82-86$ & 150 & 75 & \\
$86-92$ & 50 & 18 & $z=1.75$ \\
$92-98$ & 50 & 6 & $Z=4.7 ; P<0.001$ \\
\hline
\end{tabular}

Table 4: Effect of pH on outcome of NIV

\begin{tabular}{lccl}
\hline $\mathbf{p H}$ & $\begin{array}{l}\text { Number of } \\
\text { patients }\end{array}$ & $\begin{array}{l}\text { Patients requiring } \\
\text { endotracheal intubation }\end{array}$ & $\begin{array}{l}\text { Statistical } \\
\text { analysis }\end{array}$ \\
$7.2-7.26$ & 150 & 100 & \\
$7.26-7.34$ & 50 & 8 & $Z=10.6 ; P<0.001$ \\
$7.35-7.42$ & 50 & 10 & $Z=5.8 ; P<0.001$ \\
\hline
\end{tabular}


Table 5; Figure 5). Patients who deteriorate after $48 \mathrm{~h}$ of NIV (late failures) had poor outcome $(P<0.001$, Table 6; Figure 6).

\section{Discussion}

A number of studies have looked at predictors of outcome fro NIV in acute exacerbations of COPD. ${ }^{[1,2,9-11]}$ Acidosis is an indicator of the severity of decompensation in acute on chronic ventilatory failures and has been shown to predict death or patient requiring endotracheal intubation owing to acute exacerbation of COPD. ${ }^{[2,9,11]}$

\begin{tabular}{lccl}
\hline Table 5: Effect of pedal edema on outcome of NIV \\
\hline Pedal & Number of & Patients requiring & Statistical \\
edema & patients & endotracheal intubation & analysis \\
Present & 100 & 70 & $Z=6.2 ; P<0.001$ \\
Absent & 150 & 20 & \\
\hline
\end{tabular}

Table 6: Effect of late failures on outcome of NIV

\begin{tabular}{|c|c|c|c|}
\hline $\begin{array}{l}\text { Late } \\
\text { failures }\end{array}$ & $\begin{array}{l}\text { Number of } \\
\text { patients }\end{array}$ & $\begin{array}{l}\text { Patients requiring } \\
\text { endotracheal intubation }\end{array}$ & $\begin{array}{l}\text { Statistical } \\
\text { analysis }\end{array}$ \\
\hline $\begin{array}{l}\text { Deterioates } \\
\text { after } 48 \mathrm{~h}\end{array}$ & 100 & 70 & \\
\hline $\begin{array}{l}\text { Does not } \\
\text { deterioate }\end{array}$ & 150 & 30 & $\begin{array}{l}z=8.3 \\
P<0.001\end{array}$ \\
\hline
\end{tabular}

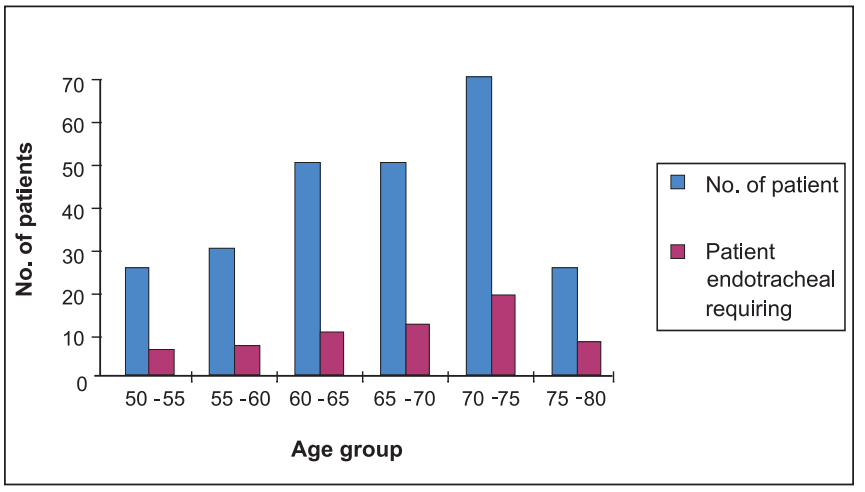

Figure 1: Shows impact of age on outcome of NIV

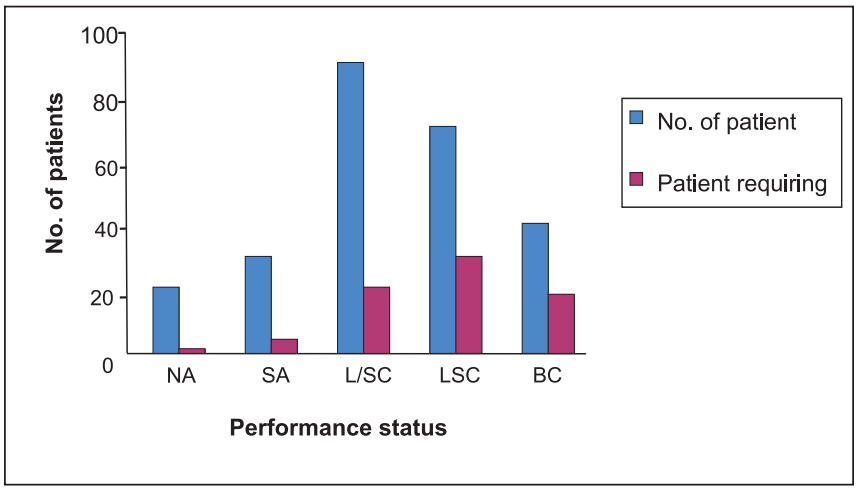

Figure 2: Shows impact of performance status on outcome of NIV

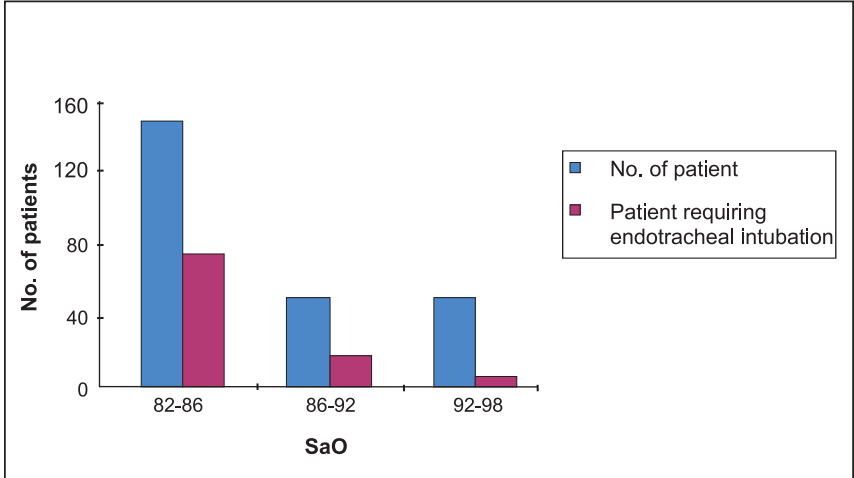

Figure 3: Shows impact of oxygen saturation $\left(\mathrm{SaO}_{2}\right)$ on outcome of NIV

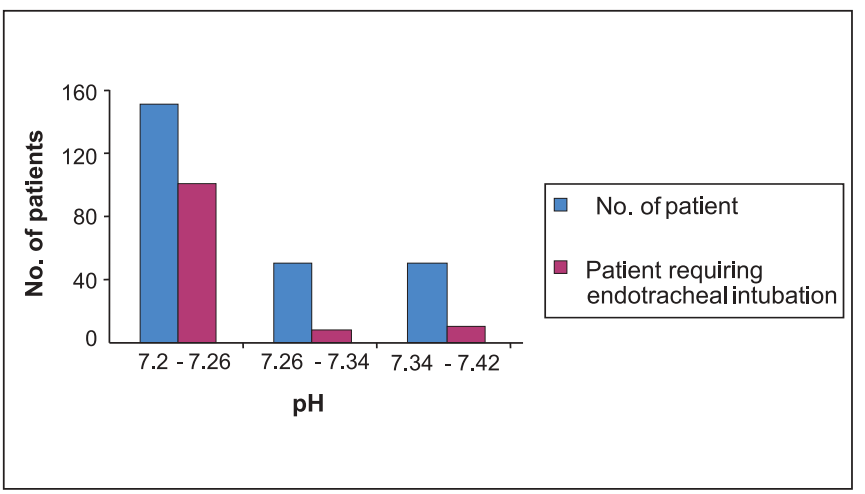

Figure 4: Shows impact of pedal edema on outcome of NIV

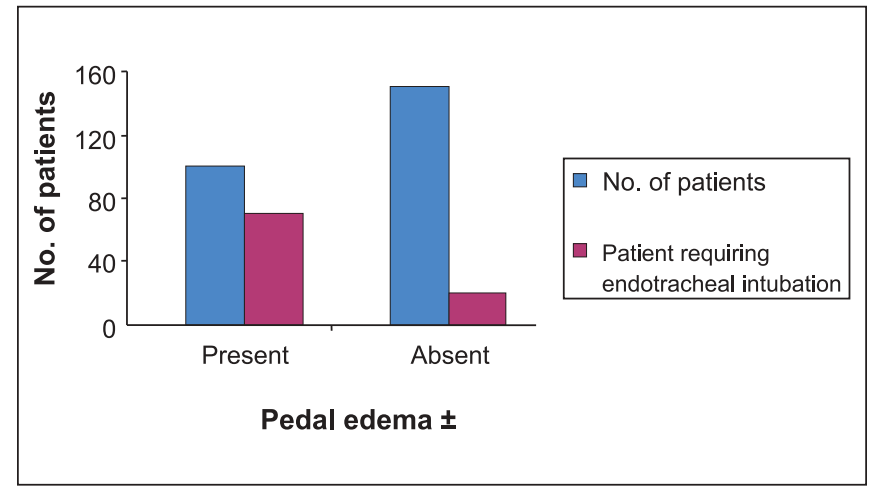

Figure 5: Shows impact of pH on outcome of NIV

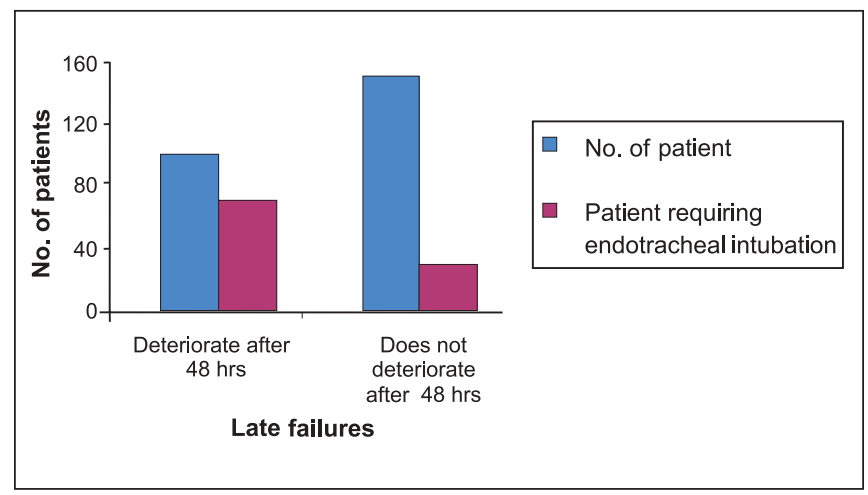

Figure 6: Shows impact of late failures on outcome of NIV 
Ambrosino et al. found that patients in whom NIV treatment failed were significantly more acidemic at baseline than those successfully treated. Although using discriminant analysis, a number of variables had a predictive value of more than 0.80 for successful NIV, when tested together using regression analysis, only baseline $\mathrm{pH}$ remained as a significant predictor for successful NIV, with a sensitivity of $91 \%$ and specificity of $71 \%$. Brochard et al. ${ }^{[1]}$ found that success was less likely with a lower starting $\mathrm{pH}$.

Ambrosin et al. ${ }^{[12]}$ found that better compliance was associated with a greater likelihood of success with NIV. Studies have concentrated on the ability to predict failures shortly after initiation of NIV. However, patients who fail NIV do not exclusively fail at this time. Late failures (deteriorating after $48 \mathrm{~h}$ of NIV) are recognized with rates reported at $0-20 \%$ and have been associated with poor outcomes. ${ }^{[13]}$ Age in our study was unrelated to outcome, a fact consistent with the observation of other authors, ${ }^{114-}$ ${ }^{16]}$ indicating that NIV needs not be denied to older patients. In our study patients with limited self-care or patient with a low level of consciousness carry poor prognosis-the result is in accordance to the American Respiratory Care Foundation, ${ }^{[17]}$ which stresses that altered consciousness should be a relative contraindication for NIV, given that confused patients are likely to adapt poorly to NIV as a result of impaired collaboration.

Oxygen saturation $\left(\mathrm{SaO}_{2}\right)$ at the time of admission can predict outcome of the patient, as in our study, but no randomized control trial had been done earlier addressing this issue.

Patient with pedal edema indicating right-sided cardiac failure (cor-pulmonale) carries poor prognosis. This may be owing to the fact that peripheral pooling of blood further compromises oxygen delivery to the tissues, thereby increasing the work of breathing, which may lead to respiratory failure.

In conclusion, acidemia $(\mathrm{pH}<7.2)$ should be considered as an absolute indication for endotracheal intubation. As seen in our study, out of 150 patients with $\mathrm{pH}<$ 7.26, 100 (66\%) patients had to undergo endotracheal intubation; therefore, in our opinion, such patients should be spared of the discomfort of NIV, and should be taken up for invasive ventilation at the time of admission with- out a trial of NIV. Other variables, viz., late failures, performance status of limited self-care, $\mathrm{SaO}_{2}(<86 \%)$, and presence of pedal edema, should be considered as relative contraindication to NIV. No difference in the outcome was noticed with increasing IPAP and EPAP (Table 6; Figure 6). No serious adverse effects were noticed. The minor complications were mild-to-moderate nasal bridge injury (25\% of patients), conjunctivitis (6\%), and gastric distension (2\%).

\section{Conclusion}

Acidosis is the most important predictor of outcome of NIV. As seen in our study that out of 150 patients with $\mathrm{pH}<7.26,100$ (66\%) patients had to undergo endotracheal intubation, therefore, in our opinion such patients should be spared of the discomfort of NIV, and should be taken up for invasive ventilation at the time of admission without giving trial of NIV, whereas other variables, viz., late failures, performance status of limited self-care, $\mathrm{SaO}_{2}(<86 \%)$, and the presence of pedal edema should be considered as relative contraindication to NIV.

\section{References}

1. Brochard L, Mancebo J, Wysocki M, Lofaso F, Conti G, Rauss $A$, et al. Noninvasive ventilation for acute exacerbation of chronic obstructive pulmonary disease. N Engl J Med 1995;333:817-22

2. Bott J, Carroll MP, Conway JH, Keilty SE, Ward EM, Brown AM, et al. Randomized controlled trial of nasal ventilation in acute ventilatory failure due to chronic obstructive airway disease. Lancet 1993;341:1555-7.

3. Kramer N, Meyer TJ, Meharg J, Cece RD, Hill NS. Randomized, prospective trial of noninvasive positive pressure ventilation in acute respiratory failure. Am J Respir Crit Care Med 1995;151:1799-806.

4. Celikel T, Sungur M, Ceyhan B, Karakurt S. Comparison of noninvasive positive pressure ventilation with standard medical therapy in hypercapnic acute respiratory failure. Chest 1998;114:1636-42.

5. Plant PK, Owen JL, Elliott MW. A multicentre randomized controlled trial of the early use of non invasive ventilation for acute exacerbation of chronic obstructive pulmonary disease on general respiratory wards. Lancet 2000;355:1931-5.

6. Nourdine $\mathrm{K}$, Combes $\mathrm{P}$, Carton MJ, Beuret $\mathrm{P}$, Cannamela $\mathrm{A}$, Ducreux JC. Does noninvasive ventilation reduce the ICU nosocomial infection risk? A prospective clinical survey. Intensive Care Med 1999;25:567-73.

7. Wood KA, Lewis L, Von Harz B, Kollef MH. The use of noninvasive positive pressure ventilation in the emergency de- 
partment. Chest 1998;113:1339-46.

8. Ambrosino N. Noninvasive mechanical ventilation in acute respiratory failure. Eur Respir J 1996;9:795-807.

9. Soo Hoo GW, Hakimian N, Santiago SM. Hypercapnic respiratory failure in COPD patients. Chest 2000;117:169-77.

10. Jeffrey $A A$, Warren PM, Flenley DC. Acute hypercapnic respiratory failure in patients with chronic obstructive lung disease: risk factors and use of guidelines for management. Thorax 1992;47:34-40.

11. Warren PM, Flenley DC, Millar JS, Avery A. Respiratory failure revisited: acute exacerbation of chronic bronchitis between 196168 and 1970-76. Lancet 1980;1:467-70.

12. Ambrosino N, Foglio K, Rubini F, Clini E, Nava S, Vitacca M. Non-invasive mechanical ventilation in acute respiratory failure due to chronic obstructive airway disease: correlates for success. Thorax 1995;50:755-7.
13. Moretti M, Cilione C, Tampieri A, Fracchia C, Marchioni A, Nava $S$. Incidence and causes of non-invasive mechanical ventilation failure after initial success. Thorax 2000;55:819-25.

14. Soo Hoo G, Santiago S, Williams AJ. Nasal mechanical ventilation for hypercapnic respiratory failure in chronic obstructive pulmonary disease: determinants of success and failure. Crit Care Med 1994;22:1253-61.

15. Wysocky M, Tric L, Wolff MA, Gertner J, Millet H, Herman B. Non-invasive pressure support ventilation in patients with acute respiratory failure. Chest 1993;103:907-13.

16. Pennock BE, Kaplan PD, Carlin BW, Sabangan JS, Magovern JA. Pressure support ventilation with a simplified ventilatory support system administered with a nasal mask in patients with respiratory failure. Chest 1991;100:1371-6.

17. Shneerson JM. The changing role of mechanical ventilation in COPD. Eur Respir J 1996;9:393-8. 